KANDOLKA Zita

\title{
Mozaikok a holland közoktatási rendszerről
}

\section{Pár személyes jellegü információ - mintegy bevezetésként}

A 2007/2008-as tanévben, egy uniós program keretében, sikeres pályázat útján kerültem Hollandiába. A Voorthuisen városában müködő Van den Bergh Általános Iskola hívott meg. Feladatom döntően az volt - mintegy a tanári kar tagjaként - hogy megismertessem a saját hazám kultúráját az ottani diákokkal. Ott tartózkodásom lehetőség volt arra is, hogy bepillantást nyerjek a holland oktatási rendszerbe és kultúrába. A Hollandiában eltöltött tanév, eddigi szakmai pályafutásom egyik legérdekesebb állomása volt. A helyi pedagógusközösség tagjaként aktívan részt venni egy másik európai ország pedagógiai munkájában, hatalmas élmény volt számomra. Ráirányította a figyelmemet arra is, hogy érdeklődéssel szemléljem az Európai Unió más országai és a hazai oktatási rendszer különbségeit és hasonlóságait.

\section{A holland közoktatásról általában}

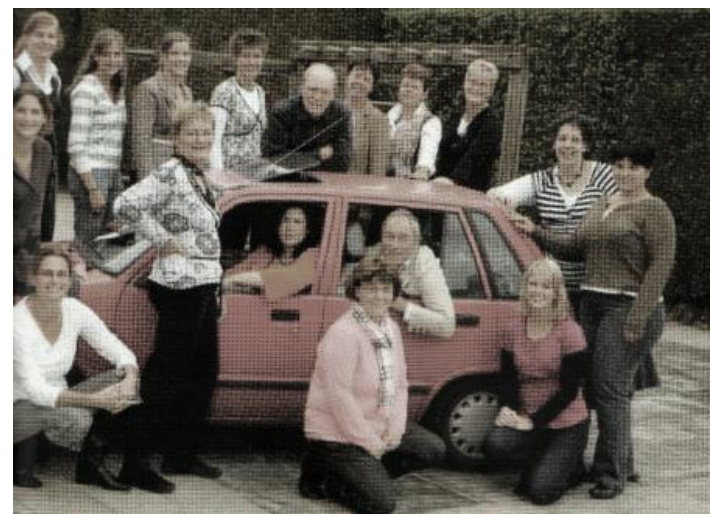

1. ábra A tanári team Voorthuizenben

Hollandia területe $41526 \mathrm{~km}^{2}$, lakossága 16500000 fö, népsürüsége $397 \mathrm{fö} / \mathrm{km}^{2}$, és 12 tartományra tagolódik. Államformája 1815-ben lett alkotmányos monarchia, és 1848 óta parlamentáris demokrácia. A holland parlament tekintélyes befolyással rendelkező része, az Alsóház (Tweede Kamer), amelynek 150 tagját négyévente választják meg.

Hollandia egyik legfőbb jellemzője a liberális demokrácia, mind a mai napig koalíciós kormányok irányítják. Az oktatási intézmények fenntartói hálózata sokszínü, méltán büszkeség tárgya az ottani szakemberek szemében. Régóta müködnek itt az alternatív iskolák is, pl. Montessori, Waldorf, Jena-terv, Freinet, Dalton-terv. A holland oktatás a nemzetközi felmérések szerint is sikeresnek mondható. (Az Európai Unióban átlag felettinek számító holland eredmények a hazai eredményeket túlhaladják, de világviszonylatban csak átlagosak.) Az országban a tankötelezettségi korhatár 2007-ig 5 évestöl 16 éves korig tartott, 2007 óta azonban 18 éves korig írja elő a tankötelezettséget a jogi szabályozás. Hollandiában az alkotmány rendelkezik arról, hogy az oktatásügyet a törvényhozás szabályozza, és a Központi Kormány irányítja. A Központi Kormány felelős a teljes oktatási rendszer fenntartásáért, a felügyeleti normák érvényesülésért, valamint az oktatás szervezéséért és a vizsgáztatásért. Az oktatáspolitika letéteményese az Oktatási és Tudományos Minisztérium, döntéseit egyezteti és megvitatja az iskolafenntartókkal, a pedagógus szakszervezetekkel és a szülöi és diákszövetségekkel. A tényleges oktatásért és annak tartalmáért hosszú időn át gyakorlatilag az intézmények feleltek, teljes mértékben gyakorolva ezzel szakmai autonómiájukat. ${ }^{1}$

\footnotetext{
${ }^{1}$ Jelenleg - az iskolafenntartók, a pedagógus szakszervezetek, a szülői és diákszövetségek bizonyos belátásának és felvilágosult előre látásának köszönhetően - a holland oktatási rendszer nehézkesen ugyan, de elmozdulóban van egy sajátos centralizálódás felé, megtartva azonban a különféle társadalmi képviseletek befolyását az oktatásügyre.
} 


\section{A holland közoktatás finanszírozói és müködtetöi}

Hollandiában bárki alapíthat közoktatási tevékenységet folytató iskolát, ha megfelel bizonyos követelményeknek. Az állam az oktatási költségeket fenntartótól függetlenül megtéríti, minden közoktatási intézmény esetében. A szülői (legtöbbször önkéntes) hozzájárulásokat nem számítva az oktatás teljesen ingyenes, vagy nagymértékben támogatott. $\mathrm{Az}$ oktatásfinanszírozásban - az állami szerepvállalás meghatározó jellege mellett - kiemelkedő fontosságú a gazdaság szereplöinek közremüködése, különösen a szakképzés megvalósításában. Itt található Európában az egyik legkiterjedtebb duális rendszer, ami átfogja a szakképzés minden szintjét, most már olykor a föiskolai képzést is beleértve. ${ }^{2} \mathrm{Ez}$ a konstrukció az, ami talán az egyik legdemokratikusabb rendszernek mondható Európában. A kormány ugyanakkor az oktatás teljes finanszírozása mellett - mint fentebb már említettük elöír bizonyos mennyiségi és minőségi normákat (például a minimum tanulói létszám is ilyen), amelyeknek meg kell felelnie az oktatási intézményeknek.

Az országban közel 80\%-ban magán kézben vannak az iskolák. Ez összehasonlítva a magyarországi magán oktatási intézmények hozzávetőleges 10\%-ával, nagyon nagy különbség. Hollandiában négy domináns iskolafenntartó és iskolaszervezeti hálózat müködik, a katolikus és a protestáns egyházak, valamint a nem egyházi magánfenntartású és az állami. A kommunikációt konzultatív bizottságok segítik, amelyek minden iskolai szinten megtalálhatók. A holland minisztériumok és a holland oktatás szereplői között müködő fórumok és egyeztetések - mint már a fentiekben említettem - nagy fontossági erővel bírnak az oktatáspolitikai irányelvek megfogalmazódása és az oktatás gyakorlati müködtetésének területén. A helyi önkormányzatok is jelentős szerepet töltenek be az oktatási rendszerben, ugyanis a hozzájuk területileg rendelt oktatási intézményekben hatóságként müködnek. Feladatuk - többek között - a tankötelezettség betartásának ellenőrzése, ezen kívül számos végrehajtási kötelezettségük van, valamint közremüködnek az állami fenntartás és müködés finanszírozásának területén, mint koordináló és elosztó szerv.

\section{A holland oktatási rendszer kialakulásáról}

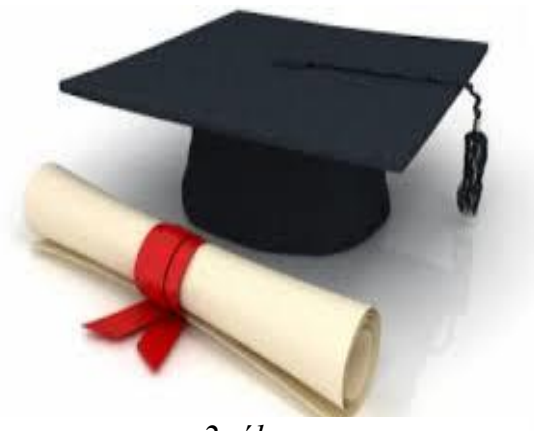

2. ábra

Forrás:

https://eduardvanbrakel.files.wordpress .com/2014/12/diploma.jpg

Hollandiában a 17. század elejéig nem volt kiforrt oktatási rendszer és az egyházak domináns szerepet játszottak az oktatás irányításában. Az ország tekintélyes egyetemei közismertek voltak és nagy számban fogadták a tanulni vágyókat szerte Európából. Ebbe a kialakult gyakorlatba az állam lassanként beavatkozott. Kezdetben csak a vallási világnézeti különbségekből fakadó ellentétek „kivédése” megelőzése érdekében, később - a polgárosodás előrehaladtával - lépésről lépésre haladva, átvette az oktatási rendszer teljes irányítását. Az első oktatási törvényt 1801-ben hozták Hollandiában, ami egyáltalán nem tükrözte a napjainkig jellemző liberális és decentralizált képet. Ez a törvény korlátozta a szabad iskolaalapítást és erősen beszabályozta az iskolák müködését, tananyagát is. Az egyházi és más magán iskolák alapítását ellehetetlenítette. Elismerte ugyan a már

\footnotetext{
${ }^{2}$ Volán Elektronika Zrt.: Tanulmány 15 európai uniós tagország szakképzéseiben alkalmazott pályakövetés módszereiről, a pályakövetéses vizsgálatba bevont célcsoportokról, a tevékenységet megalapozó jogi szabályozásról, a pályakövetést segítő intézmények rendszeréröl http://site.nive.hu/konyvtar/content/edoc/files/Szakmai_anyag_15EUorsz_palyakov.pdf
} 
meglévőket, de újak létesítésére csak ritkán, vagy egyáltalán nem adott lehetőséget. A 19. században a magán intézmények alapításának ügye parázs vitákhoz vezetett, aminek eredménye képen az 1848-ban elfogadott Holland Alkotmány már teret engedett az állami fenntartású intézmények mellett, többek között az egyháziaknak is. Ez az alkotmány szabadságot hirdetett az oktatásban és az állam szerepét az oktatási intézmények alkalmasságának ellenőrzésére redukálta. Az állami intézmények elszakadva az egyházi intézményektől, semleges világnézetü szellemben müködtek tovább. Ez feszültséget teremtett, mivel az állam elzárkózva a magán alapítású iskoláktól, nem vállalt részt azok finanszírozásában, anyagiakkal csak az állami iskolákat támogatta. A feszültség a magasabb követelmények és az oktatás tényleges színvonala között egyre nőtt. A magán iskolák és egyházak érdekképviseletei, a 19. század végére elérték, hogy az állam részben támogassa a nem államhoz tartozó oktatási intézmények müködését is. Az általános nemzeti összefogás ami felismerte, hogy a tolerancia a jövő útja - fordulatot harcolt ki a holland oktatási rendszerben. Az állam engedett a többségi akaratnak és követeléseknek, így létrejött az oktatás finanszírozásának egyenlősége, megszüntetve ezzel a társadalmi feszültségeket is ezen a területen. (Mivel a politikai irányzat általában is a kölcsönös türelemre és toleranciára épült, ez az oktatás területén is dominánsan jelentkezett). Az állami nyomásból végre kilépve megszaporodtak a magán fenntartású intézmények, melyek önálló arculattal rendelkeztek. Az 1900-as évek végére - mint fentebb már szó volt róla - a magán intézmények száma jócskán meghaladta az állami intézmények számát.

\section{3. ábra}

A nyilvános oktatás és a magánoktatás arányának változása 1860 és 1990 között

\begin{tabular}{|l||c||c||}
\hline \hline $\mathbf{E} \mathbf{v}$ & Nyilvános oktatás & Magánoktatás \\
\hline 1860 & $79 \%$ & $21 \%$ \\
\hline \hline 1920 & $55 \%$ & $45 \%$ \\
\hline 1950 & $27 \%$ & $73 \%$ \\
\hline 1990 & $31 \%$ & $69 \%$ \\
\hline
\end{tabular}

Forrás: KOPP ERIKA: Keresztény oktatás Hollandiában http://vigilia.hu/regihonlap/2000/5/kop0005.html\#J2

\section{A holland oktatási rendszer felépítése}

Az oktatási rendszer maihoz már hasonlatos, de kezdetben eléggé merev formáját 1985-ben vezették be. Ekkor jelent meg a nyolc osztályos elemi iskola. Ez az erősen behatárolt oktatási rendszer csak kevés átjárási lehetőséget biztosított a tanulóknak a közép-, illetve felsőfokú oktatás területén. Az elemi iskolában, a tanulók kb. 12 éves korában, a tanulmányi teljesítmény alapján, szinte már el is dőlt, hogy hol, és milyen szinten folytathatja tovább tanulmányait egy-egy tanuló. ${ }^{3}$

Ez a szelektáló gyakorlat és módszer - amellett, hogy nem volt praktikus és demokratikusnak sem volt nevezhető - hamarosan arra ösztönözte az oktatásfejlesztőket, hogy

\footnotetext{
${ }^{3}$ A rendszer müködése hasonló volt az Egyesült Királyságban ma is alkalmazott 11+ vizsga néven ismertfelvételi eljáráshoz. (Részletesebben ld. Nagy Katalin: Konzervativizmus és liberalizmus. Pályaválasztás és társadalmi mobilitás az Egyesült Királyság közoktatási rendszerében. Opus et Educatio 1. évfolyam 1. szám 60-64p.)
} 
a középfokú oktatás és felsőfokú oktatás területén, az intézmények közötti átjárhatóság megkönnyítése irányában tegyék nyitottabbá a holland közoktatást. Az ezredfordulón az átjárható iskolarendszer megvalósulni látszott, Hollandia az oktatást kulcsfontosságú területként kezelve, tovább emelte annak színvonalát és sikeresen megvalósította annak megújított szerkezeti elképzeléseit.

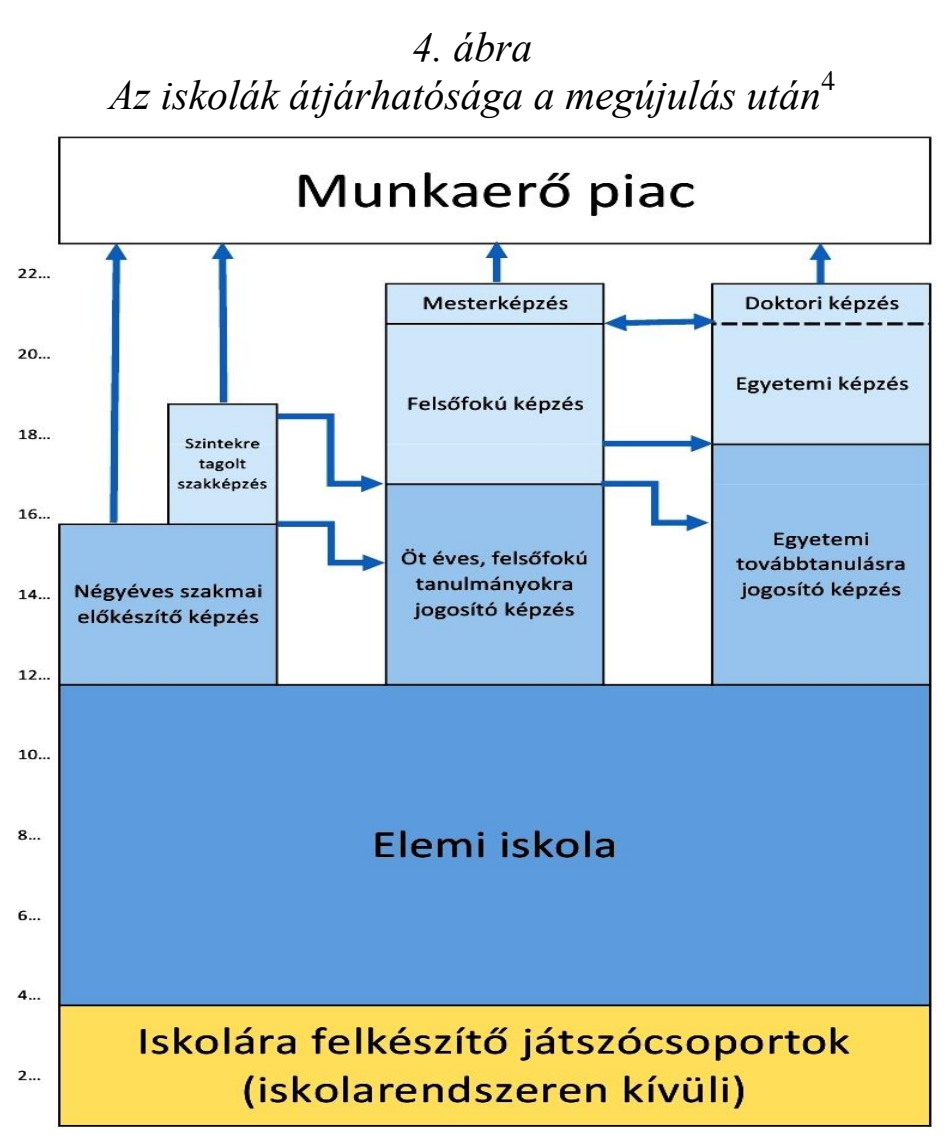

A költségvetésből az állam nagyarányú pénzösszegeket különített el az oktatás számára és a megreformálás az elmúlt két évtizedben folyamatosan zajlott az országban. Az oktatáspolitika jelenleg is lankadatlanul törekszik arra, hogy az oktatás színvonalának emelése érdekében, új és új reformokat, szabályokat vezethessen be, de az oktatást jelento régi „gerinc”, ami tiszteletben tartja az autonóm és egyéni jogokat megmaradt. (Kezd ugyanakkor általánossá válni az a nézet, miszerint egy megfelelően centralizált és szabályozott rendszer vezet majd a cél eléréséhez, vagyis a holland oktatás átütő minőségi javulásához.) Ezek a nézetek egyelöre csak óvatosan és kis lépésekben valósulnak meg a liberális demokrácia államában.

\footnotetext{
${ }^{4} \mathrm{http} / / / \mathrm{www} \cdot \mathrm{microsofttranslator.com} / \mathrm{bv} \cdot \mathrm{aspx}$ ?from=\&to=hu\&a=http\%3A\%2F\%2Fhistoforum.net $\% 2$ Fhistory\%2 Fsystem.htm
} 
A holland oktatási rendszer felépitése és a megszerezhetö végzettségek 2009

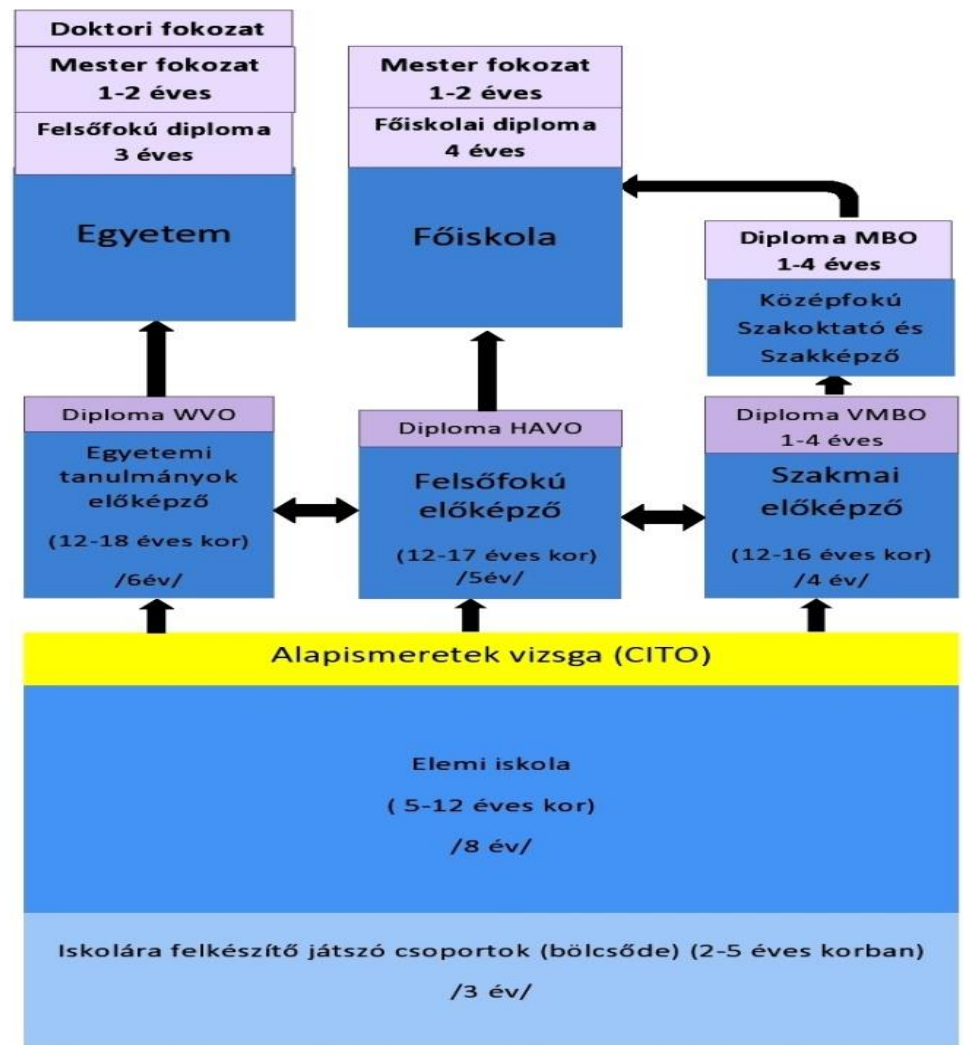

Forrás: http://www.ncee.org/programs-affiliates/center-on-internationaleducation-benchmarking/top-performing-countries/netherlands-overview/

Hollandiában a tankötelezettség 5 éves korban kezdődik, de az alapfokú oktatásban régóta bevett gyakorlat az elemi iskolát már négy éves korban elkezdeni, mivel erre adottak a jogszabályi lehetőségek. A négyévesnél fiatalabbak játszó csoportokba járhatnak, kicsit hasonlóan a hazai bölcsődei ellátáshoz (2-4 éves korban). Az ilyen, korai iskola előtti nevelést, oktatást ellátó intézmények ${ }^{5}$ gyakran az iskolai életre való felkészítést is vállalják, azonban kevés kivételtől eltekintve ezek nem ingyenes, nem alanyi jogon járó szolgáltatásokAz általános iskolák ${ }^{6}$ előkészítő csoportban kezdődnek, az előkészítő oktatás az elemi oktatás részeként, 4-től 6 éves korig tart. ${ }^{7}$ Az előkészítő szakasz legfontosabb feladata bevezetni a gyerekeket az iskolai életbe és a számok betük, fogalmak, viselkedési normák világába. Maga a szorosabban vett általános iskolai oktatás 12 éves korig tart és vizsgával zárul. A vizsgaköteles tantárgyak (többek között a matematika, egészségügyi ismeretek, angol nyelv, holland nyelv és történelem) tartalmát és a minimum követelményeit, amiknek a tanulóknak meg kell felelniük az oktatás végére, ma már erősen szabályozzák. A tanulmányok végén közel 15 tantárgyból vizsgázhatnak már a tanulók, de a vizsgatárgyak a fent említett kötelező elemeken kívül, szinte szabadon variálhatóak, szem elött tartva a folytatni kívánt tanulmányok szakmai jellegét, a továbbhaladás bemeneti elvárásait, a tehetség és érdeklődés

\footnotetext{
${ }^{5}$ VVE, voor- en vroegschoolseeducatie/ Kidergarden, EarlyChildhood Education

${ }^{6} \mathrm{BAO}$, basisonderwijs, ElementarySchool, PrimarySchool - elemi általános iskola

${ }^{7} \mathrm{Ez}$ nagyjából megfelel a magyar óvodák vegyes csoportjainak, de nem önállók, egy elemi iskola keretein belül müködnek.
} 
irányát. A kötelező tárgyak tanítási módszereiről még mindig az iskolák határoznak, sőt, ezen felül választhatnak, hogy mivel és hogyan bővítik a tanítandó tantárgyaik körét.

A sajátos nevelési igényü tanulók Hollandiában más utat járhatnak be tanulmányaik alatt. Az integrált képzés itt választható, de nem kedvelt forma. A szülők a sajátos nevelési igényü gyerekeket speciális iskolákba járatják inkább, ahol hozzájuk igazodó tanterv szerint tudják elsajátítani a sajátosságaikhoz adekvát tananyagokat. Az általános iskolától, egészen a felsőfokú szakmai, vagy elméleti képzésü intézményekben is tanulhatnak speciális körülmények között ${ }^{8}$.

Néhány évvel ezelőtt, az általános iskola után egy fél éves pályaorientációs felkészítő képzésen kellett részt venniük a tanulóknak. Ez mára megváltozott, ezt az eredeti funkcióját a régi formájában már nem tölti be. Az oktatás következő szintjén már szerteágazó, meglehetősen szelektív továbblépési lehetőségek állnak rendelkezésre. Markáns tulajdonsága a holland oktatási rendszernek, hogy a különbözö tanulmányi utak hierarchikusan követik egymást, amelyek között - mint ahogyan azt fentebb már említettük - az átjárás a képzés közben is (bizonyos feltételek mellett) lehetséges.

A tanulók az elemi iskola elvégzése után választhatnak az általános és a szakképzés között. Lehetőségük van - a középfokú oktatás területén belül - hat éves, egyetemi képzésre jogosító tanulmányokra ${ }^{9}$, vagy öt éves szakföiskolai tanulmányokra jogosító képzésre ${ }^{10}$. A magyar motivációs gyakorlattal ellentétben - számomra meglepő módon - a hollandok többsége nem a magasabb iskolai képzéshez vezetö útra lép még akkor sem, ha eredményei alapján, vagy a rendszernek köszönhetően lehetösége lenne rá.

Kimutatások szerint legtöbben a négy éves (VMBO) szakmai előkészítő képzésben vesznek részt és mindössze kb. $15 \%$ választja az elméleti általános képzést. ${ }^{11}$ Igaz, hogy Hollandiában a magasabb szintü tanulmányok jóval nehezebben járható képzési utat jelentenek, mint általában más országokban. A különböző szintek között nagy az eltérés a követelményeket illetően. Aki a holland rendszerben tovább tanul a felsőfokú képzésben ${ }^{12}$ (aminek folyatatásaként elérhető a mesteri fokozat), az eljuthat a legmagasabb szintü tanulmányokig, ${ }^{13}$ az egyetemi, vagy főiskolai képzésig, aminek végén elérhető a doktori fokozat. ${ }^{14}$

\footnotetext{
${ }^{8}$ SBAO: speciaalbasisonderwijs/ Specialprimaryeducatio - Speciális általános iskola; SO: speciaalonderwijs/ Specialeducation - speciális általános képzés; VSO: voortgezetspeciaalonderwijs/ Secondaryspecialeducation középfokú speciális képzés

${ }^{9}$ VWO,Wetophetvoortgezetonderwijs, Pre-universityeducation - Egyetemi továbbtanulásra jogosító elöképző képzés

${ }^{10} H A V O$, hogeralgemeenvoortgezetonderwijs, General SecondaryEeducation - öt éves, föiskolai tanulmányokra jogositó képzés

${ }^{11}$ Ez a jelenség is hasonló az Egyesült Királyságban tapasztalható továbbtanulási pályaképekhez.

(Részletesebben ld. Nagy Katalin fentebb hivatkozot írását. Opus et Educatio 1. évfolyam 1. szám 60-64p.)

${ }^{12}$ HBO: hogerberoepsonderwijs, Professional Higher Education - Felsőfokú képzés,

${ }^{13} \mathrm{WO}$ : wetenschappelijkonderwijs, Academichighereducation - egyetemi képzés

${ }^{14} \mathrm{http}: / / \mathrm{www}$.microsofttranslator.com/bv.aspx?from=nl\&to=hu\&a=http\%3A\%2F\%2Fwww.government.nl\%2Fis sues $\% 2$ Feducation $\% 2$ Fprimary-education
} 


\title{
A holland szakképzésröl
}

\author{
6. ábra
}

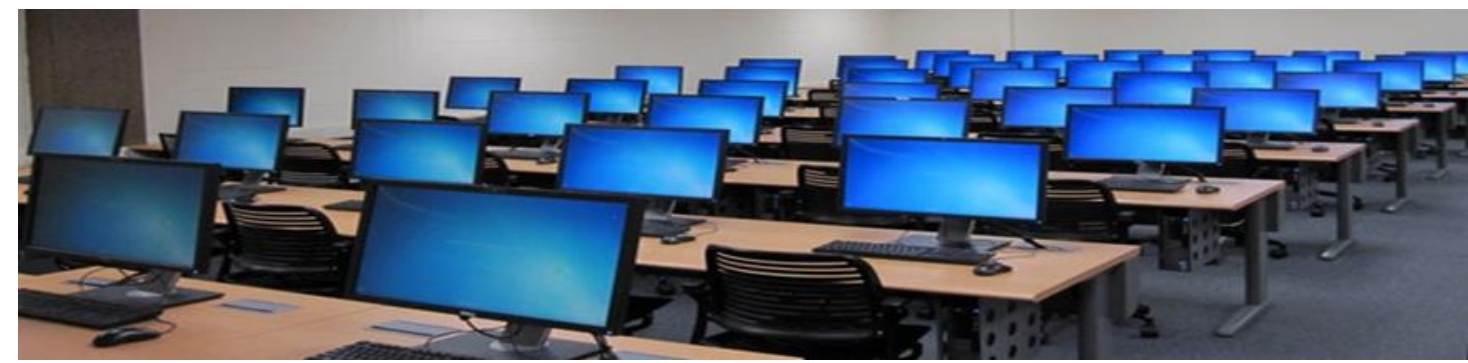

Forrás: http://www.bonque.nl/blog/het-nederlands

A szakképzés ebben az országban a kilencvenes évek vége óta jól bevált rendszerként müködik. A 90-es években a szakmajegyzék felülvizsgálata után, elindult a moduláris képzés. Az országban sokrétü képzési rendszert alakítottak ki, nagy hangsúlyt fektetve az egyéni döntésre és felelősségre. Az átjárhatóság és a modularitás - amelyeket csak egy-egy szint befejezése után vesznek figyelembe - kompenzációs, változtatási lehetőséget biztosítanak. ${ }^{15}$ A tanulók a túlnyomóan gyakorlati képzésü intézmények keretein belül a szakma saját környezetében sajátíthatják el az ismereteket, az emellett működő (választható), túlnyomóan elméleti képzés hasonló a magyar rendszerben általánosan megszokott szakmai képzéshez.

Az iskolaelhagyás és lemorzsolódás megelőzése érdekében Hollandia egy regisztrációs rendszert müködtet. A fiataloknak 23 éves korukig rendszeresen jelezniük kell, hol tartanak tanulmányaikban és szükség esetén segítséget, ösztönzést kapnak az oktatási rendszerbe való visszataláláshoz, vagy a továbbhaladáshoz. A regisztrációs rendszerrel a kapcsolattartás 18 éves korig kötelező, és ezzel nagymértékben hozzájárul a szakképzettség megszerzéséhez, valamint a sikeres elhelyezkedéshez a munkaerő piacon. Bár a tankötelezettség az országban 18 éves korig tart, de a fiataloknak 16 éves koruk betöltése után lehetőségük van, un. részidős képzésben tanulni. Ez azt jelenti, hogy a tanulás mellett már munkát tudnak vállalni, vagy más tanulmányi utakat tudnak bejárni. İgy a jog által garantált bérminimummal teljes értéküen megjelenhetnek a munkaerő piacon, és tanulmányaik alatt is szert tehetnek igazolható (figyelembe vett) szakmai gyakorlatra. Hollandiában az elemi általános iskola elvégzése után a tanulók közel 75\%-a választja a szakmai továbbtanulást.

A szakmai képzés első lépcsője a négy éves szakképzési előkészítő iskola. ${ }^{16}$ Ennek elvégzése után kezdhetik meg középfokú szakmai tanulmányaikat. A 16-20 évesek, a szakképzés területén négy szintre tagolódóan tanulhatják a holland szakképzési jegyzék szerinti 700-nál is több szakmát. Itt is választási lehetőségük van a túlnyomóan gyakorlati (üzemi, vagy gyári) BBL képzés ${ }^{17}$, vagy a túlnyomóan elméleti BOL oktatási forma ${ }^{18}$ között. A BBL tömbösített formájú szakképzésben a gyakorlat aránya több mint $60 \%$, míg a BOL hagyományos képzési forma esetén a gyakorlat aránya $20 \%$.

\footnotetext{
${ }^{15}$ Volán Elektronika Zrt.: Tanulmány 15 európai uniós tagország szakképzéseiben alkalmazott pályakövetés módszereiről, a pályakövetéses vizsgálatba bevont célcsoportokról, a tevékenységet megalapozó jogi szabályozásról, a pályakövetést segítő intézmények rendszeréröl http://site.nive.hu/konyvtar/content/edoc/files/Szakmai_anyag_15EUorsz_palyakov.pdf

${ }^{16} \mathrm{VMBO}$, voorbereidendmiddelbaarberoepsonderwijs, Pre-vocationalsecondaryeducation - Négy éves szakmai előkészítő képzés

${ }^{17} \mathrm{BBL} / \mathrm{MBO}$,beroepsbegeleidendeleerweg/middelbaarberoepsonderwijs, Blockordayreleaseinvocationaleducation/secondaryvocational(- tömbösített formájú szakképzés $60 \%$ fölötti gyakorlati aránnyal)

${ }^{18}$ BOL, beroepsopleidendeleerweg, Full-timevocationalprogrammes - elmélet orientált szakmai képzés
} 
A holland szakképzés átalakítása után ez a kezdeti forma is változóban van, a fiatalság által választható különböző stratégiai utak folyamatosan bővülnek. E meglehetősen szövevényes folyamatok eredményeként létrejött egy vegyes képzési stratégia, amely általános képzési elemeket ötvöz a szakképzési elemekkel, ez utóbbiak javára eltolódva. Ebben a formában heti tíz óra a gyakorlati szakképzés. E forma mellett létezik még a szakképzés-orientált stratégia, amely a rövid távú középfokú szakképzésben ${ }^{19}$ való részvételt teszi lehetővé, heti kb. 6 órás gyakorlati képzéssel összekapcsolva és a hosszú távú szakképzés-orientált stratégia, amely a hosszú távú szakképzésben való részvételt (HBO) alapozza meg. Itt a gyakorlat is több: kb. heti húsz óra. ${ }^{20}$

A holland szakképzési intézmények jellemzően különféle szinteken, különböző szakmákat oktatató gigantikus méretü oktató központok, amelyek általában 2000 körüli tanuló létszámmal rendelkeznek. Ennek egyrészt gazdasági okai vannak, de a továbblépés és a tanulmányi útváltás lehetőségének megkönnyítése érdekét is szolgálják. Az ország szakképzésében regionális szinten a Regionális Oktatási Centrumok (ROC) és az Agrár Oktatási Centrumok (AOC) dominálnak. Az állami intézmények mellett müködnek magántulajdonban lévő képzési központok is, ilyen a Paepon országos szervezet, amelynek kb. száz intézménye van. „A ROC-ok szakmai irányítását olyan Intézményi Tanács (board) végzi, amelyben különbözö szervezetek, intézmények (például a helyi önkormányzatok, cégek, vállalkozások, egyházi szervezetek) képviseltetik magukat. Feladatuk a kapcsolattartás a munkaadói és munkavállalói szervezetekkel, valamint intézményi szinten a képzésben szereplö szakmacsoportok, tananyagok, tantervek meghatározása. A képzö központ irányítási feladatait a board-ok alatt elhelyezkedö management, mint a ROC igazgatósága végzi. Ugyanolyan bürokráciával rendelkezik, mint bármely más, a magánszektorban tevékenykedö vállalkozás. Pénzügyi finanszírozása nagyrészt az Oktatási Minisztériumon keresztül zajlik. A kapott pénzösszeget saját belátásuk szerint használhatják fel, a ROC-ok, beszámolási kötelezettségük sincsen. Amennyiben felnőttképzésben is részt vesznek ezek a képzö központok, a Munkaügyi Minisztérium is hozzájárul a költségekhez. Az adott intézmény bevételeinek maximum 40\%-a származhat egyéb tevékenységböl - például cégeknél végzett tréningek bevétele -, de ez általában nem haladja meg az 5\%-ot. Minden regionális képzési központ képviselteti magát az országos szintü szakképzési tanácsban. Hasonló jellegü tanács fogja össze a mezögazdasági intézményeket. A magánoktatásban az ezeknek megfelelö szervezet a Paepon."

Ezekben a szakképzö intézményekben megszerezhetö szakképzési szintek a képzések végén:

- Alsóbb szakképesítés, vagy asszisztensi szint

- Alap-szakképesítési szint

- Szakképesítés

- Középfokú szakképzési szint (Aki ezt a szintet eléri, az tanulmányait magasabb szinten is folytathatja).

A képzések végén a felsőfokú szakképzés után a mester szint elérhető ugyan, de ehhez be kell járni az eddig elöírt összes tanulmányi utat.

\footnotetext{
${ }^{19} \mathrm{MBO} 1$,2,3,4: middelbaarberoepsonderwijs , Vocationaleducation - Négyszintű szakképzés

${ }^{20}$ Volán Elektronika Zrt.: Tanulmány 15 európai uniós tagország szakképzéseiben alkalmazott pályakövetés módszereiröl, a pályakövetéses vizsgálatba bevont célcsoportokról, a tevékenységet megalapozó jogi szabályozásról, a pályakövetést segitő intézmények rendszeréröl/ https://www.nive.hu/.../Szakkepzesi.../Szakkepzesi.../DL.php?...

${ }^{21}$ Platform van Aangewezen/Erkende Particuliere Onderwijsinstellingen in Nederland/ Elismert magán oktatási intézmények Hollandiában.
} 
A felnőtt képzés Hollandiában ${ }^{22}$ szintén a központi intézményekben zajlik. Sajátossága a holland szakoktatásnak és vizsgarendszernek, hogy a szakképzést az első 5 évig az állam finanszírozza, de a gyakorlati képzés és vizsgáztatás költségeinek nagyobb részét a gazdaság vállalja magára. A vállalkozások közel egyharmada vesz részt az oktatásban és biztosít „, gyakorlati terepet" a tanulóknak. Érdekesség még a holland szakképzésben, hogy kapcsolódik hozzá egy un. pályakövető rendszer, amelynek célja az, hogy évente adatokat szolgáltasson a szakmai végzettséget szerzett fiatalok munkaerőpiaci helyzetéről, beválásukról. ${ }^{23}$

\section{A holland oktatási rendszer jövöképéröl}

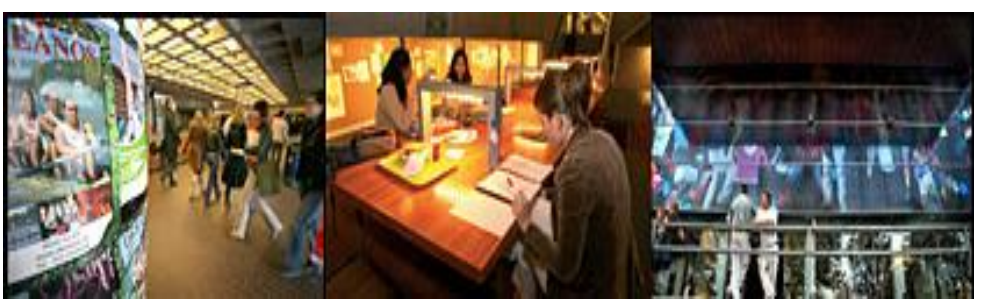

7. ábra

Forrás:http://www.vu.nl/en/programmes/studying-at-vu/dutcheducation/

Az Európai Szakképzés-fejlesztési Központ kiadványainak keretében megjelent, helyzetkép és tervek melyekben az európai országok képzését hasonlítják össze, még inkább bepillantást nyerve a holland oktatási rendszerbe megállapítható, hogy Hollandia is a folyamatos változás útját járja. Az ország következetesen szeretne javítani oktatásán, amelynek érdekében szüntelenül törekszik a megújulásra. Az európai unió „zászlói alatt” a többi európai országhoz hasonlóan közös célok megfogalmazásával hasonló elvek mentén halad és újul tovább, szándéka szerint pozitív irányba befolyásolva a kulturális és társadalmi alakulást az oktatáson keresztül. A jövőkép az unión belül egységesnek mondható. Az európai uniós oktatási stratégia a 2010-től, 2020-ig tartó időszakra megfogalmazta az irányvonalat, a tagországok oktatásának közös céljait, aminek következtében számítani lehet a holland oktatási rendszer további átalakulására ${ }^{24}$. A tervek között szerepel az általános iskolától kiindulva egy választható gyakorlatorientált képzés, ami egészen az elemi általános iskolától kezdi el felépíteni a szakmai képzést, sajátos pedagógiai és képzési programmal. A szakmai képzést a különböző területek kiemelésével folytatnák, maximálisan tekintettel a munkaerőpiac különböző igényeire. Az elképzelések szerint az alapoktatást hat képzési formában lehet majd választani, az alábbi iskolatípusok közül (alacsony és magasabb szintű képzési formában):

- A gyakorlati oktatás (VMBO GL)

- Alsó szintü képzés (alsó-BBL)

- Elmélet orientált képzési út (alsó-KBL)

- Elmélet központú képzés (VMBO-TL)

- Főiskolai tanulmányokra jogosító képzés (HAVO)

- Gimnázium (VWO)

\footnotetext{
${ }^{22}$ BVE: MiddelbaarBeroepsonderwijsen VolwassenenEducatie, Secondaryvocationaleducation and adulteducation- Szakképzés és felnőtt képzés

${ }^{23}$ Volán Elektronika Zrt.: Tanulmány 15 európai uniós tagország szakképzéseiben alkalmazott pályakövetés módszereiről, a pályakövetéses vizsgálatba bevont célcsoportokról, a tevékenységet megalapozó jogi szabályozásról, a pályakövetést segítő intézmények rendszeréröl

http://site.nive.hu/konyvtar/content/edoc/files/Szakmai_anyag_15EUorsz_palyakov.pdf

${ }^{24}$ Europa 2020 in Nederland : http://ec.europa.eu/europe2020/europe-2020-in-your-country/nederland/countryspecific-recommendations/index_nl.htm
} 
A felsőfokú képzésben megjelenik majd a tervek szerint egy nyitott egyetem, amin indítatása szerint bárki képezheti magát. A holland tervek szerint az oktatás szerkezete várhatóan bonyolultabb és szerteágazóbb lesz, ugyanakkor színesebb képzési palettával fog rendelkezni, de ez már a jövő kihívása a holland oktatási rendszer számára. ${ }^{25}$

\section{Felhasznált forrásanyagok}

Ballendux-Bogyay Mária: Hollandia magyar szemmel - Budapest: Akad. K. 2008 Blaauwendraat, Evert: A klasszikus oktatástól a személyre szabott oktatásig : Az oktatás és a képzés megújitása Hollandiában- A pedagógusképzés megújítása. - Budapest: Gondolat Könyvkiadó, 2006. - p. 18-36.

Boot, Anneke: A civil társadalom és az oktatás Nyugat-Európában:Hollandia-Új Pedagógiai Szemle 45. évf. 1. sz. (1995), p. 75-79.

Europa 2020 in Nederland : http://ec.europa.eu/europe2020/europe-2020-in-yourcountry/nederland/country-specific-recommendations/index_nl.htm

Kandolka Zita: Magyarország, Románia és Hollandia oktatási rendszereinek összehasonlitó elemzése c. szakdolgozat, BME GAZDASÁG- ÉS TÁRSADALOMTUDOMÁNYI KAR, Alkalmazott Pedagógia és Pszichológia Intézet Müszaki Pedagógia Tanszék - Közoktatási vezető és pedagógus-szakvizsga szakirányú továbbképzési szak, Budapest 2014 (pp.3542)

Kopp Erika; [ford. Kiss Gabriella]: A pedagógusképzés megújítása : A Reformpedagógiai Kutatócsoport kiadványa, Budapest, Gondolat K., 2006

http://refernet.hu/szakkepzes-az-europai-unioban/

http://www.cedefop.europa.eu/en/publications-and-resources/publications/8065

http://www.microsofttranslator.com/BV.aspx?ref=IE8Activity\&a=http\%3A\%2F\%2Fwww.ia mexpat.nl $\% 2$ Fread-and-discuss $\% 2$ Feducation $\% 2$ Farticles $\% 2$ Foverview-dutch-schoolsystem-part-one

Volán Elektronika Zrt.: Tanulmány 15 európai uniós tagország szakképzéseiben alkalmazott pályakövetés módszereirōl, a pályakövetéses vizsgálatba bevont célcsoportokról, a tevékenységet megalapozó jogi szabályozásról, a pályakövetést segítö intézmények rendszeréröl -

http://site.nive.hu/konyvtar/content/edoc/files/Szakmai_anyag_15EUorsz_palyakov.pdf http://www.freedutch.nl/node/45

http://www.vu.nl/nl/opleidingen/index.asp

http://www.bonque.nl/blog/het-nederlands

http://www.microsofttranslator.com/bv.aspx? from=nl\&to=hu\&a=http $\% 3 \mathrm{~A} \% 2 \mathrm{~F} \% 2 \mathrm{Fwww} \cdot \mathrm{gov}$ ernment.nl\%2Fissues\%2Feducation\%2Fprimary-education

http://www.ncee.org/programs-affiliates/center-on-international-education-benchmarking/topperforming-countries/netherlands-overview/

http://wetten.overheid.nl/BWBR0002399/geldigheidsdatum_23-10-2014

Houdende Wet op het basisonderwijs-

http://wetten.overheid.nl/BWBR0003420/geldigheidsdatum_23-10-2014

http://egykisfoldrajz.freeiz.com/Hollandia.html

\footnotetext{
${ }^{25}$ http://refernet.hu/szakkepzes-az-europai-unioban/
} 